\title{
Assessing the Relationship Between Multilevel Marketing and Employment Reduction in Ondo State, Nigeria
}

\author{
Mezie-Oscar, V.O \\ Department of Business Administration, Adekunle Ajasin University, Akungba Akoko, Ondo State \\ Dada, D.A \\ Department of Business Administration, Achievers University, Owo, Ondo State
}

\begin{abstract}
This research investigated the effect of multilevel marketing on unemployment reduction in Akure, Ondo State. Primary data collected from one hundred and seventy five (175) respondents of Longrich distributors/partners were used for the analysis. The study employed a multiple regression model. The result of the regression analysis revealed that there is a direct and significant relationship between multi-level marketing and employment opportunities in Akure, Ondo State. The study concluded that that unemployment will be reduced if Multi-level marketing patronage is sustained. Finally, the study recommended, among others, that since there is a positive relationship between MLM and employment reduction, government should create enabling business environment for the companies using multilevel marketing strategy in order to bring more on board for investment to generate further employment.
\end{abstract}

Keywords: Multi-level Marketing, Unemployment, Distributors, Partners, Patronage.

DOI: $10.7176 / \mathrm{EJBM} / 13-21-07$

Publication date: November $30^{\text {th }} 2021$

\section{SECTION ONE}

1.1 Introduction

Unemployment has become a plaque ravaging most developing countries of the world and there is no end in sight despite the various programmes and policies put in place by concerned governments and other stakeholders. In Nigeria, the situation is the same. Consequently, many people have been devising legitimate means to wriggle themselves out of the menace. Many considered Multi-Level Marketing (MLM) as an escape route out of the precarious situation. It is instructive to note that Multi-Level Marketing is a form of direct selling in which products are distributed through network of independent distributors/members/partners instead of the well-known traditional distribution channel. It is also known as Network Marketing or Referral Marketing.

The advantages inherent in Multi-Level Marketing (MLM) are legion. For instance, in marketing, multilevel marketing minimized huge cost of advertisement especially for firms that devotes huge amount of money on promoting their new and existing products in forms of television commercials, newspapers and other online media. it is one of the best alternatives now as it is capable of empowering individuals by possibilities it offers them to participate in easy-to-start business that provide significant revenue yields if well worked and create more Entrepreneurs. More importantly, in this era of widespread unemployment, Multi-level marketing has the capacity to be a veritable source of job creation, revenue generation, and poverty reduction.

However, in spite of the growth of Multi-marketing, unemployment has also turned a major macro-economic challenge confronting Nigeria. In fact, the unflinching menace of unemployment has led to so much violence, disaster, increase in fraud and so much unhealthy social vices. The National Bureau of Statistics (2019) lent credence to this and posited that unemployment rate in Nigeria stood at 27.1 percent in the second quarter of 2020 , the highest on record. This situation is particularly worrisome as critical questions have been raised on the situation: to what extent has multilevel marketing influence unemployment in Nigeria? What is the relationship between multi-level marketing and employment opportunities in Akure metropolis?

To this end, it is important to note that different entrepreneurial strategies have been suggested. However, to the best of the researcher's knowledge, studies on Multi-Level Marketing as a panacea to unemployment reduction in Nigeria is still lacking in literature. The few available Multilevel marketing studies were not tailored toward employment reduction. For instance, Effiom and Archibong (2015) investigated the Role of Multilevel Marketing (MLM) in Poverty Alleviation while Amina, Mukhtar and Mukhtar (2018) examined the moderating role of distributor's job satisfaction with special emphasis on distributor's retention. The closest to the present research is the study of Sourav, Singlab and ShashiShashia(2015) that used a confirmatory factor analysis approach to only investigate the motivational factors in multilevel marketing business without any recourse to unemployment reduction. The present study is a clear departure from the aforementioned studies as it studies multilevel marketing within the matrix of unemployment reduction. Against this background, the main objective of the study is to examine Multi-Level Marketing as a panacea for unemployment reduction in Ondo state, Nigeria. Specifically, the study attempted to establish the effect of Multi-level marketing on employment opportunities in Akure metropolis. 
Following this introduction, the remaining parts of the paper is organized as follows: Section two covers the literature review and the theoretical underpinnings. Section three present the methodology of the study. Data analysis and interpretation of result is the main thrust of section four while section five draws up policy recommendation and conclude the paper.

\section{SECTION TWO}

\section{Literature Review}

\subsubsection{Concept of Multi-Level Marketing}

Multi-level marketing (also known as network marketing or person to person marketing) is the type in which the direct seller makes money from both direct sales to customers and by sponsoring new direct sellers and earning commission from their sales and sponsoring other direct sellers too. In addition, Multilevel Marketing is a specific form of direct selling and is also known as 'multilevel marketing' or 'multilevel direct selling' (Muncy, 2004). It involves retailing based on face to face communication between a selling agent and a potential buyer (Brodie , Stanworth and Wotruba, 2002; Kustin and Jones, 1995; Msweli and Sargeant, 2001). These distributors or agents get commissions, discounts or other considerations for their direct sales as well as for indirect sales made by their down-lines (Koehn, 2001; Higgs and Smith, 2007; Coughlan and Grayson, 1998).

According to Biggart (1989), multilevel marketing business is not only an economic action but also a potent social model. Multilevel marketing involves both social as well as monetary swap (Frezen\&Davis, 1990). Wotruba (1992) found that people who were attracted by factors such as social rewards, the sense of self satisfaction and achievement and bendy working hours normally have higher output in multilevel marketing.

Multilevel marketing distributors share the knowledge and skills with each other (Pratt, 2000).

According to Bandura (1991) multilevel marketing provide opportunity for its distributors to improve their personality. Social environment formed by multilevel marketing groups plays an important role in motivating its distributors (Bhattacharya \& Mehta, 2000; Biggart, 1989; Sparks \& Schenk, 2006). Under the social environment of multilevel marketing, different types of events are organized regularly and successful distributors share their personal success stories with others, this is an important strategy used by Multilevel marketing distributors to attract prospects (Biggart, 1989; Kuntze, 2001, Bhattacharya \& Mehta, 2000; Pratt, 2000.). Steve (2016) maintained that MLM and other direct sales channels facilitate employment facilities to interested people which results in social and economic development of Nation but there is need of strict regulations against working of these types of direct selling channels. According to Chonko and Caballero (1989) Multi-Level Marketing or Network Marketing is a type of Direct Selling in which an independent distributors or networkers representing manufacturer's products.

\subsubsection{Concept of Unemployment}

The Central Statistics Office (CSO), defines the unemployed as not only those non-employed that are currently job-seekers but also includes those non-active workers that looked for work during the three-month period preceding the interview and who at the time of interview did not have a job but still wanted work. According to U.S. Bureau of Labour Statistics (BLS), Unemployment is defined as the unemployed workers who have become discouraged by a tough labour market and are no longer looking for work.

In addition, the International Labour Organization (ILO) maintained a person is unemployed if the person is; (a) not working (b) currently available for work (c) seeking work. The Statistical Office of the European Union defines unemployed as those people's age 15 to 74 who are not working, have looked for work in the last four weeks, and ready to start work within two weeks and the Eight International Conference on Labour Statistics held at Geneva in 1954 defined unemployment as unemployed person above a specific age who is without a job and seeking work for pay or profit. The International Conference of Labour Statistician in 1954 adopted the standard international definition of unemployed as: Persons in unemployment consist of all persons above a specific age who, on the specified day or for a specified week, are in the following categories:

Workers available for employment whose contract of employment has been terminated or temporarily suspended and who is without a job and seeking work for pay or profit. Persons who are available for work (except for minor illness) during the specified period and are seeking work for pay or profit, who are never previously employed or whose most recent status is other than that of an employee, i.e., former employers etc. or who has been in retirement and persons on temporary or indefinite layoff without pay. The following categories of persons are not considered to be unemployed: Persons intending to establish their own business or farm, but who has not yet arranged to do so, who are not seeking work for pay or profit and former unpaid family workers not at work and not seeking work.

\subsection{Theoretical Literature}

\subsubsection{Maslow's Hierarchy of Needs Theory}

Abraham Maslow in his famous article, A Theory of Human Motivation, propounded the hierarchy of needs theory. It was anchored on satisfaction of human needs. The theory proposes that people are motivated by multiple needs 
and these needs exist in a hierarchical order. The five levels of needs identified by Maslow are accordingly, physiological needs, safety needs, social needs, esteem needs, and self-actualization. Physiological needs are also called survival needs and include the deeds for food, shelter and clothing. They (the physiological needs) exert a stupendous influence on behaviour because they are necessary for man's existence. According to Rao cited by Izueke, physiological needs dominate when all needs are unsatisfied.

Consequently, in applying the theoretical framework of hierarchy of needs to this study, it is held that at the level of poverty challenge, all needs are unsatisfied. The physiological needs accordingly become and remain pronounced. In essence, in the application of this theoretical framework to the study, it is proposed that income security is primarily for the satisfaction of the citizen's physiological needs. Citizens that lack food, shelter and clothing are poor. They require income (income security) to fight poverty, and satisfy the occasioning physiological needs. Is the satisfaction of these needs (invariably, the reduction in the level of unemployment which leads to alleviating the poverty challenge) through the mechanism of multilevel marketing, achievable? It is in these regards that the study is framed on the hierarchy of needs theory. The challenge of satisfying these needs move more and more citizens to become network marketers.

\subsection{Empirical Review}

Abdul and Sarada (2012) examined the significance of the relationship between multilevel marketing and its effect on business outcome. A total of 614 distributors and customers were sampled. The paper described the problems of multilevel marketing and set out a research paradigm to investigate the influence of relationship in building network which is a prerequisite for the better performance of distributors in Multi-level marketing in Kerala's environment.

Furthermore, Abdul, (2013) examined the influence of demographics on the perception level of Multilevel Marketing Distributors. The study describes the problems and sets out a research paradigm to investigate the influence of demographics on the perception level of multilevel marketing distributors. The study concluded that a right perception towards multilevel marketing is a prerequisite in building a wide network that will eventually results in better performance in the field. In addition, Sourav, Singlab and Shashi Shashia (2015) in their own studies investigate the motivational factors in multilevel marketing business using a confirmatory factor analysis approach. It was discovered that most of the MLM companies focused on compensation plan or reward system but apart from that a number of variables have been found which motivate the distributors to engage in MLM business.

In Colombia, William and Maria (2016) looked at international expansion opportunities for multi-level marketing via personal networks. The paper noted that although multi-level marketing (MLM) and direct sales companies have risen, controversies and ethical concerns in recent years, MLM has rapidly expanded to developing and emerging markets in the last decades. The ethnographic research found that several multi-level and direct sales companies provide international income opportunities, but do not contribute to the increase of formal jobs creation.

Gbadeyan and Olorunleke(2014) studied customer perception towards MLM in Ilorin, Nigeria. They focused on three prominent MLM operating in Nigeria comprising Forever Living, GNLD and Tianshi. The study found that small amount required to start the program was a major motivating factor to entrepreneur. In the same vein, Effiom and Archibong (2015) investigated the Role of Multilevel Marketing (MLM) in Poverty Alleviation in Calabar - Cross River State, Nigeria. Structured questionnaires were served on a total of 300 respondent distributors of the company and the data generated were analysed using the Pearson Product Moment correlation statistical technique. The result of the hypotheses tested showed that there is a strong positive relationship between MLM and job creation on the one hand, and MLM and income generation on the other. The study recommends that government should provide incentives to MLM companies to establish production plants in the country to exploit local economies and stem the tide of unemployment, among many other benefits.

Okeke and Nwankpa (2017) examined the relationship among accounting fundamentals in multilevel marketing, income security and the poverty challenge in Nigeria. The research hypothesis is that there is no positive relationship among these variables. The study found that at the level of poverty challenge all needs are unsatisfied. It is held in the study that income security in this country is primarily for the satisfaction of the citizen's physiological needs. Findings of the study thus led to the conclusion that the application of accounting principles (accounting fundamentals) is critical to effectiveness in multilevel marketing.

In another study, Amina, Mukhtar and Mukhtar (2018) examined the moderating role of distributor's job satisfaction on the relationship between multilevel marketing (MLM) and distributor's retention. The paper utilized the sample of fifty (65) respondents, while a valid response of 77 percent was obtained. The face and content validity of the instruments were found to be appropriate for their study.

Finally, Oladele and Laosebikan (2019) assessed the perception of financial variants of Multilevel marketing Strategy and Growth of Network Marketing Companies in Nigeria. The study used a total of two hundred and two MLM Entrepreneurs of Swissgolden, AIM Global and Longrich using Google form online survey. The data for the study were analyzed using descriptive and inferential statistics. It was revealed from the study that there is a significant relationship between the financial variants and motivation to Join MLM. The study therefore 
recommended that entrepreneurs should take due care in selecting MLM they signed up with.

\section{SECTION THREE \\ Methodology}

3.1 Research Design

This study adopted descriptive research design which is a scientific method that involves observing and describing the behaviour of a subject without influencing it in any way. This research design was chosen because of its ability to reduce any bias and the collection of authentic data import for the data analysis.

\subsection{Population of the Study}

The population of this study comprise of all distributors/partner in the selected MLM Company in Akure (Longrich Bioscience International). The company was purposively selected because it is the only one out of all other MLM companies in Nigeria that has its manufacturing plant built in Nigeria. The number of respondents became the population for the study which is 175 .

\subsection{Sample Size and Sampling Technique}

The distributors of Longrich products of selected state, otherwise refers to as partners in this study, form the population from which samples were drawn for the study. Sampling was, however, restricted to those who are registered members as distributors and those who have used at least one of the Longrich products in the last one year. This was to ensure that they qualify as consumers and distributors of Longrich products. Since it will be practically impossible to obtain a list of all Longrich distributors in the population because multiple registrations are allowed and new recruit are coming in on minute bases online, the non-probability method of sampling was opted for. Of the non-probability sampling methods commonly used, purposive or judgmental was thought to be more appropriate for in this case and was used in the selection of the distributors for this study. The sample size is 175 which is the total number of the respondents.

\subsection{Validity and Reliability of the Research Instrument}

In ensuring the reliability of the instrument, a Cronbach's alpha test for consistency of the items of the questionnaire was conducted using stata the value of $\alpha$ range from $0-1$, hence, the closer the value of $\alpha$ to 1 , the more acceptable the reliability of the instrument (Fisher, 2010). This was satisfactory which showed the instrument was reliable

\subsection{Scope of the Study}

Different multi-level marketing companies abound in Nigeria. However, the scope of this study is limited to Longrich Bioscience International in Akure Metropolis, of Ondo State, because of the presence of its large member customers $\backslash$ distributors that are spread across the city.

\subsection{Method of Data Collection}

Data were collected mainly from primary sources through the use of questionnaires. Sekeran (2003) added that in using an online survey, the number of respondents inclined to participate in the survey constitute the sample size. The questionnaire comprised was administered via online platforms such as Longrich distributors/partners/ Whatsapp group chats and Facebook pages using a link (Link: https://forms.gle/iwWCqiYebUB6JCgP8).

\subsection{Model Specification}

The regression model was represented by the following equation: $E M P=E M P=\beta_{0}+\beta_{1} I G+\beta_{2} P Q+\beta_{3} T F+\beta_{4} R S+\beta_{5} C I+\beta_{6} C P+\beta_{7} J S+\varepsilon$

Where IG, PQ,TF,RS, CI, CP and JS are respectively Income generation, Product quality, Time freedom, Reward system, Company image, Compensation plan and Job satisfaction while EMP denotes unemployment reduction and $\mathrm{E}$ as error term.

The theoretical Apriori expectations of the model are:

$\beta_{1}-\beta_{6}>0$.

In theoretical terms, it is expected that any improvement or increase in the income generation, product quality, time freedom, company image, compensation plan and job satisfaction is expected to increase employment generation by a certain percentage.

\subsection{Method of Data Analysis}

Two type of data analysis were carried out on data collected. Descriptive statistics, which include frequency counts, and tables, were used to analyse and interpret the data. Regression Analysis was used. The significant level for test is 0.05 . 


\section{SECTION FOUR}

Data Presentation, Analysis and Interpretation

4.1 Socio-Demographic Characteristics of Respondents

Table 4.1Socio-Demographic Characteristics of Respondents

\begin{tabular}{|c|c|c|c|}
\hline Characteristics & & Frequency & Percentages (\%) \\
\hline \multirow[t]{3}{*}{ Gender } & Male & 22 & 12.6 \\
\hline & Female & 153 & 87.4 \\
\hline & Total & 175 & 100.0 \\
\hline \multirow[t]{7}{*}{ Age group } & $16-25$ & 22 & 12.6 \\
\hline & 26- 35 & 77 & 44.0 \\
\hline & $36-45$ & 61 & 34.9 \\
\hline & $46-55$ & 12 & 6.9 \\
\hline & $56-65$ & 2 & 1.1 \\
\hline & 65 and above & 1 & .6 \\
\hline & Total & 175 & 100.0 \\
\hline \multirow[t]{7}{*}{ Educational Qualification } & O'Level & 9 & 5.1 \\
\hline & OND/A-Level & 19 & 10.9 \\
\hline & HND/B.Sc. & 111 & 63.4 \\
\hline & Masters & 22 & 12.6 \\
\hline & Ph.D. & 6 & 3.4 \\
\hline & Others & 8 & 4.6 \\
\hline & Total & 175 & 100.0 \\
\hline \multirow[t]{4}{*}{ Marital Status } & Single & 53 & 30.3 \\
\hline & Married & 120 & 68.6 \\
\hline & Divorced & 2 & 1.1 \\
\hline & Total & 175 & 100.0 \\
\hline \multirow[t]{7}{*}{ Years of Partnership } & less than a year & 81 & 46.3 \\
\hline & 1-2Years & 59 & 33.7 \\
\hline & $2-3$ & 17 & 9.7 \\
\hline & $3-4$ & 6 & 3.4 \\
\hline & $4-5$ & 2 & 1.1 \\
\hline & 5years and above & 10 & 5.7 \\
\hline & Total & 175 & 100.0 \\
\hline
\end{tabular}

\section{Source: Researcher's Computation, (2020)}

The Table 4.1 Presented the responses of Longrich partners/distributors based on demographic characteristics.

The demographic variables considered in this study were gender, age group, education qualification, marital status, and years of partnership. The analysis showed that majority of the respondents were female $(87.4 \%)$ while male were $(12.6 \%)$. This concluded that more female Longrich partners responded to the questionnaire than male. Majority of the respondents fell within a very active and productive age; those between the age of 16 - 25 years were $12.6 \%, 26$ - 35 years were $44 \%, 36$ - 45 years were $34.9 \%$, 46 - 55 were $6.9 \%$ while 56 -65 years, 65 and above were $1.1 \%$, and $0.6 \%$ respectively. This concluded that all the respondents were mature and able to give sound ethical judgement and standard with reference to answering the research questions. The highest educational qualifications of majority of the participants was HND/B.Sc. (63.4\%), followed by master's degree (12.6\%) and OND/A-level were (10.9\%), while O'level, Ph.D., and others were 5.1\%, 3.4\%, 4.6\% respectively. Thus, all the respondents were educated and therefore understood the contents, construct and importance of supplying honest answers to the research question which further justified the validity and reliability of the gathered data. Majority of the respondents were married (68.6\%), followed by singe $(30.3 \%)$, and divorced $(1.1 \%)$. This further stress that majority of them were responsible individuals. Also, 46.3\%, 33.7\%, 9.7\%, 3.4\%, 1.1\%, 5.7\% were less than a year, 1-2Years, 2-3, 3-4, 4-5, and 5years and above in partnership with Longrich which means that those that are over a year with the company are more than those that are a year and below which means they are all experienced Longrich product users. 
Table 4.4.2: Multiple Regression Model of Multi-Level Marketing and Employment Reduction in Akure Metropolis.

\begin{tabular}{|l|l|l|l|l|l|}
\hline Independent variables & Beta & T & Significance & Tolerance & VIF \\
\hline IG & .215 & 2.912 & .004 & .274 & 3.652 \\
\hline PQ & -.059 & -.657 & .512 & .189 & 5.295 \\
\hline TF & .125 & 1.462 & .146 & .204 & 4.908 \\
\hline RS & -.109 & -1.261 & .209 & .202 & 4.954 \\
\hline CI & .324 & 3.532 & .001 & .178 & 5.623 \\
\hline CP & .396 & 5.431 & .000 & .282 & 3.544 \\
\hline JS & .047 & .660 & .510 & .292 & 3.430 \\
\hline Correlational Statistics & \multicolumn{5}{|l|}{} \\
\hline Dependent variable & Multiple R & $\mathbf{R}^{\mathbf{2}}$ & Adjusted R $\mathbf{R}^{\mathbf{2}}$ & S.E of Estimate & Durbin Watson \\
\hline EMP & $.866^{\mathrm{a}}$ & .750 & .739 & 2.01402 & 2.008 \\
\hline
\end{tabular}

Source: Researcher's Computation, (2020).

This study used the multiple regression model. The factors considered were Income generation, Product quality, Time freedom, Reward system, Company image, Compensation plan, and Job satisfaction, while employment reduction is the dependent variable. The employment opportunity was significantly predicted at $\mathrm{R}^{2}=$ $0.750, \mathrm{~F}=(7,167)=71.521, \mathrm{P}<0.01$. The model explained $75 \%$ of the variation in employment opportunities in Akure metropolis. The multiple coefficient of variation (R) 0.866 depicted a strong and positive relationship between multi-level marketing and employment opportunities.

Also, the F ratio of 71.521 was statistically significant at 0.01 level. The beta weights $(\beta)$, compensation plan (CP) have the strongest influence of $39.6 \%$, followed by company image (CI) with $32.4 \%$ impact, income generation have $21.5 \%$, time freedom has $12.5 \%$, and job satisfaction has the least impact of $4.7 \%$ on employment opportunity. Hence, there is a significant relationship between multi-level marketing and unemployment reduction in Akure metropolis. This was in agreement with the study of Effiom and Archibong (2015) who investigated the role of Multilevel Marketing (MLM) in Poverty Alleviation in Calabar - Cross River State, Nigeria.

\section{SECTION FIVE}

\section{Summary, Conclusion and Recommendations}

\subsection{Summary}

This study examined the relationship between Multi-level marketing and unemployment reduction in Akure metropolis. The study made use of primary data, and was conducted using the selected community of Longrich product partners/distributor in Akure, Ondo State, Nigeria. The choice of Google form easy accessibility of gathering data via internet due to the Covid 19 lockdown. Purposive sampling technique was used to select the respondents who participated in the study. The data collected were analysed using frequency counts, tables, factor analysis, and multiple regression model. The result of multiple regression model to determine the relationships between multilevel marketing and unemployment reduction revealed that multilevel marketing was significantly predicted at $\mathrm{R}^{2}=0.750, \mathrm{~F}=(7,167)=71.521, \mathrm{P}<0.01$. Therefore, there is a significant relationship between multilevel marketing and employment opportunities in Akure metropolis.

\subsection{Conclusions}

The main thrust of this research is that multilevel marketing has serve as employment generation hub for Longrich product users in Ondo State. The conclusion, therefore, is that unemployment will be drastically reduced if Multilevel marketing patronage is sustained.

\subsection{Recommendations}

Since there is a positive relationship between MLM and employment reduction, government should create enabling business environment for this company to bring more on board for investment to generate further employment. In addition, since income generation, product quality, compensation plans, employment opportunity, job satisfaction and reward system dimensions were found to determine product users' partnership, it is recommended that the Management of Longrich should adopt them in formulating strategic marketing policies that would enhance partners intent to join the company MLM programs.

\section{REFRENCES}

Abu-Shamaa, R., Al-Rabayah, W., \& Khasawneh, R. (2015). The effect of job satisfaction and work engagement on organizational commitment. IUP Journal of Organizational Behaviour, 14(1), 7-27

Albaum, \&Peterson, R. (2011). Multilevel (network) marketing: An objective view. The Marketing Review, 11(4), 347-361 
Anjum, Z., Fan, L., Javed, M.F. \& Rao, A. (2014). Job characteristics Model and job Satisfaction. International Journal of Education and Research, 2(11), 241-261.

Bacon, D.A. (2009). Distributor success: High performance work practices in the multilevel direct channel market (Doctoral dissertation). Retrieved from ProQuest Dissertations and Theses database. (UMI No. 3352489)

Brodie, Coviello, Nicole E., Roderick J., Danaher, Peter, J. and Wesley J. (2002), 'How Firms Relate to Their Markets: An Empirical Examination of Contemporary Marketing Practices', Journal of Marketing, Vol. 66, No. 3, Jul, pp. 33-46.

Chen, D.R., \& Cheng, S. T. (1999). The study of the management of multi-level marketing network. Web Journal of Chinese Management Review, 2(1). Retrieved from http://cmr.ba.ouhk.edu.hk/cmr/pass 1999.htm

Chonko, L.B. \& Caballero, M.J. (1989). The Mature Consumer”, Baylor Business Review, 7,9-13.

Constantin, C. (2009). Multilevel Marketing- A Tool of Relationship Marketing. Bulletin of the Transilvania University of Brasovqqq, 2(51), 31-36.

Coughlan, A.T. (2012), FAQs on MLM companies. Available from http:// www.kellogg.northwestern.edu/faculty/coughlan/htm/personalpage_files/Papers/FAQs \%20on\%20MLM\% 20Companies\%207-30-2012\%20FINAL.pdf.

Coviello, Nicole E., Brodie, Roderick J. and Hugh J. Munro (1997), 'Understanding Contemporary Marketing: Development of a Classification Scheme', Journal of Marketing Management, Vol. 13, pp. 501-522

Dorcas O. A. (2016). Challenges of Urban Housing Quality: Insights and Experiences of Akure, Nigeria. rocedia - Social and Behavioral Sciences, 16(6), 260-268 Rao, V. S. (2009). Organizational Bahaviour. New Delhi: Excel books.

Dutta, A.B. \& Banerjee, S. (2014). Study of Employee Retention. International Journal of Business Management \& Research, 4(1), 83-88.

Dyer, W.G. (2001), "Network marketing: An effective business model for family owned businesses?", Family Business Review, Vol. 14, No. 2, pp. 97-104. https://doi.org/10.1111/j.1741-6248.2001.00097.x

Effiom, L. \& Effiong F. A. (2015): The Role of Multilevel Marketing (MLM) in Poverty Alleviation in Calabar Cross River State, Nigeria: A Case Study of Forever Living Product Nig. Ltd. Advances in Social Science Research Journal, 2 (2) 150B163

Emeh, I. E. J. (2012). Tackling youth unemployment in Nigeria; the Lagos state development and empowerment Programmes Initiatives. Afro Asian Journal of Social Sciences, 3(3.4), 2229-5313.

Federal Office of Statistics Abuja, (2008). Annual Abstract of Statistics. Federal Republic of

Fish, W. (2010). Philosophy of Perception: A Contemporary Introduction. New York: Routledge.

Fiske, A. P. (1992). The four elementary forms of sociality: framework for a unified theory of social relations. Psychological Review, 99 (4), 689.

Gbadeyan, R. A., \& Olorunleke, G. K. (2014). Measuring Consumers' Attitude towards Multi- level Marketing in Ilorin, Nigeria. Ilorin Journal of Management Sciences, 1(1), 42-56.

Haider, M., Aamir, A., Hamid, A.A., \& Hashim, M. (2015). A literature analysis on the importance of nonfinancial rewards for employees' job satisfaction. Abasyn Journal of Social Sciences, 8(2), 341-354.

Haider, S. A., Qureshi, M. M., Pirzada, S. S., \& Shahzadi, I. (2015). A Study of Student's Motivation and its Relationship with their Academic Performance. Journal of Resources Development and Management, 8, 918.

IFC (2000) Assessing Private Sector Contributions to Job Creation and Poverty Reduction. (http://ifc.org)ACCESSED: 22-08-2013.

Izueke, E. M. C. (2014). Some theoretical frameworks of analysis in public administration, In: O. M. Ikeanyibe and P. Mbah (Eds.): An anthology of theories for social research. Nsukka, Nigeria: University of Nigeria Press.

Khan, A.H., \& Aleem, M. (2014). Impact of Job Satisfaction on Employee Turnover: An Empirical Study of Autonomous Medical Institutions of Pakistan. Journal of Internal Studies, 7(1), 122-132

Klein, M. H. (2008) 'Poverty Alleviation through Sustainable Strategic Business Models: Essays on Poverty Alleviation as a Business Strategy'. Erasmus Research Institute of Management(ERTM). Erasmus (http://www.erim.eur.com)

Koehn, D. (2001). Ethical issues connected with multi-level marketing schemes, Journal of Business Ethics $29(1 / 2), 153-160$

Kothari C.R. (2007)"Research Methodology-Methods and Techniques" New Age International Pvt. Ltd. Publishers. http://directsellingnews.com/index.php/view/2016_dsn_global_100_list\#.V9GHqhKeNtQ

Kotler, P. \& Keller, K. (2006).Marketing Management: Setting Product Strategy. 12th ed. New Jersey: Pearson Education, Inc.

Lee, K.F., Lau, T.C., and Loi, K.Y. (2016), "Driving Distributors' Satisfaction in Multilevel Marketing Companies", Internationa Journal of Academic Research in Business and Social Sciences, Vol. 6, No. 2, pp. 
105-122. https://doi.org/10.6007/IJARBSS/v6-i2/2015

Legara, E. F., Monterola, C., Juanico, D. E., Litong-palima, M., \& Saloma, C. (2008). Earning Potential in Multilevel Marketing Enterprises. Physica A, 387, 4889-4895. https://doi.org/10.1016/j.physa.2008.04.009.

Megha S. \& Gurpreet K. (2014), Comparative Study on Amway \& Avon on the basis of MLM: International Journal of Research in Commerce, IT \& Management, Volume no.4, issue no.10, ISSN 2231-5756,Page no36

Msweli, P. and Sargeant, A. (2001), "Modelling distributor retention in network marketing organisations", Marketing Intelligence and Planning, Vol. 19, No. 7 , $\quad$ pp. $507 \quad$ - 514 . https://doi.org/10.1108/EUM0000000006215

Muncy.J. A. (2004) Ethical issues in Multi-Level Marketing: is it a legitimate business or just another pyramid scheme, Marketing Education Review, 14(3)

Nat, P.J. and Keep, W.W. (2002), "Marketing fraud: An approach for differentiating multilevel marketing from pyramid schemes", Journal of Public Policy and Marketing, Vol. 21, No. 1, pp. 139-151. https://doi.org/10.1509/jppm.21.1.139.17603

National Bureau of Statistics (2019) National unemployment rates (2012 - 2018). Retrieved from www.nigerianstat.gov.ng on 9th December, 2019.Nigeria (FRN).

Nga, J. K. H. \& Mun, S. W. (2011). The Influence of MLM Companies and Agent Attributes on the Willingness to Undertake Multilevel Marketing as a Career Option Among Youth. Journal of Research in Interactive Marketing 5 (1), 50-70.

Nijssen, E., Douglas, S.,\& Bressers, P.(1999): Attitude towards the purchase of foreign products: Extending the model.

Olubukola, S. \& Adesina (2013). Unemployment and Security Challenge in Nigeria. International Journal of Humanities and Social Science, 3(7).

Pratt, M. G. and Rosa, J. A. (2003), "Transforming work-family conflict into commitment in network marketing organisations", Academy Of Management Journal, Vol. 46, No. 4, pp. 395-418. https://doi.org/10.2307/30040635

Salami, C.G.E. (2011); Enterpreneurship and Youth Unemployment in Nigeria: The Missing Linkl.Global Journal of Management and Business Research, Volume 11 Issue 5 Version 1.0, April.

Steven W. (2016). Tell all your friends: multilevel marketing is an organizational structure for (economic and personal) growth, Global Marketing Conference at Hong Kong, http://db.koreascholar.com/article?code= 31498

Taylor, J. M. (2011). Multi-level Marketing Unmasked -The Case Against Multilevel Marketing as an Unfair and Deceptive Practice. United States of America

Vander Nat, P. J., \& Keep, W. W. (2002). Marketing Fraud: An Approach for Differentiating Multilevel Marketing from Pyramid Schemes. Journal of Public Policy and Marketing, 21(1), 139-151.

Vroom, V H \& Deci, E I (1970) Management and Motivation, Harmond sworth Penguin

Vyas PN Narayana (2005). "Network marketing - an entrepreneurial opportunity with low investment", Marketing Mastermind.

Wigren, J. (2017). Leadership challenge -An Approach to Professional Group Management in Network Marketing. Turku University of Applied Sciences.

Worre, E. (2015). GO PRO: 7 steps to becoming a network marketing professional. USA.

Yen, J., Chen, M., \& Chen, Y. (2008). The Study of Direct Selling Management Strategies: An Example of the Avon Cosmetics Company in Taiwan. Journal of International Management Studies, (February), $214-227$.

Yin, L. K. (2015). Determinants of Distributor Satisfaction in Multilevel Marketing Companies. University Tunku Abdul Rahman.

Ziglar, Z. \&Hayes, P.J. (2006), Network Marketing for Dummies, Wiley Publishing, Hoboken, NJ. 